\section{Top 5\%}
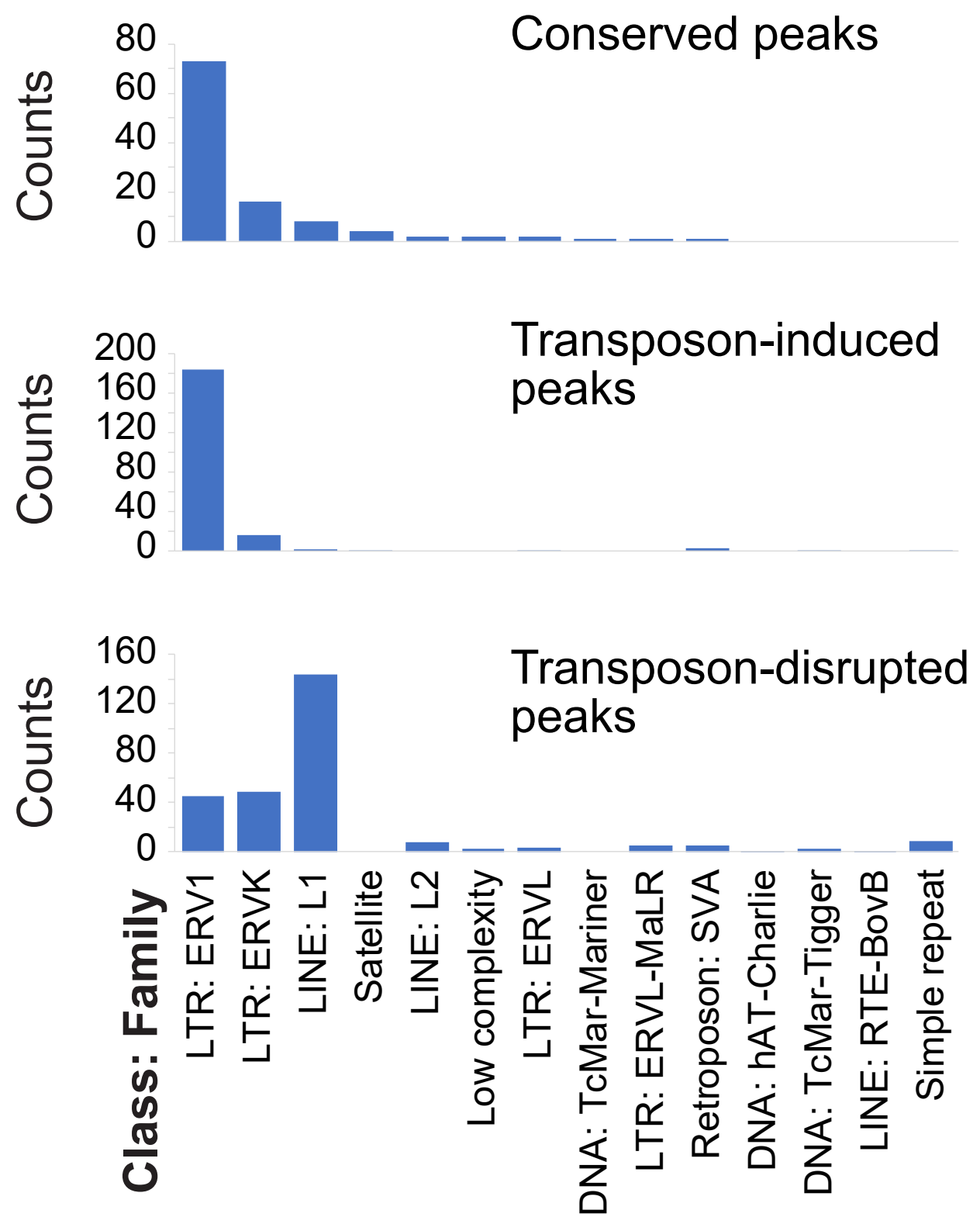

\section{Top 2\%}
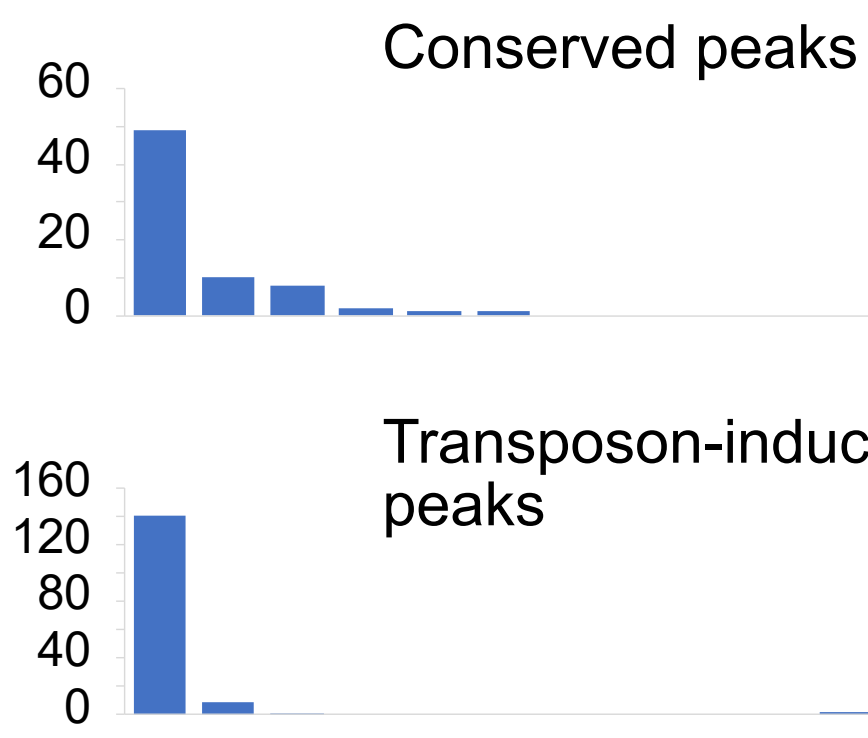

Transposon-induced peaks

Transposon-disrupted

120

80

40

0

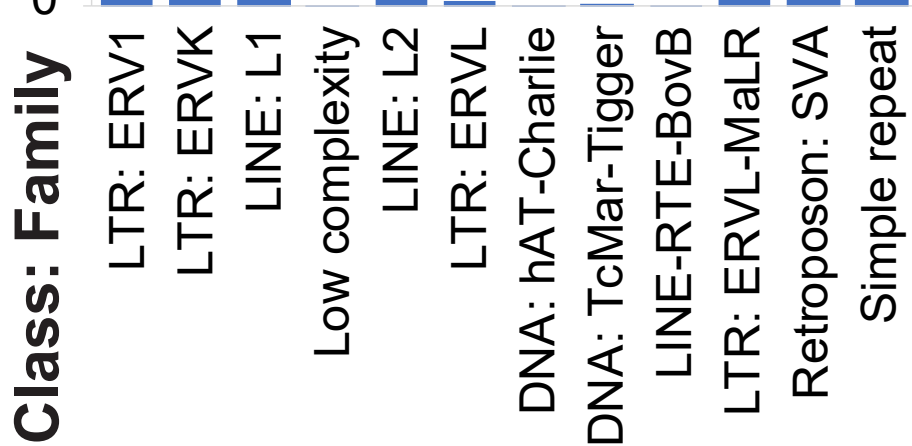

